\title{
ERASMUS: \\ His Life, Works, and Influence
}

\author{
Cornelis Augustijn \\ Translated by J.C. Grayson
}

Every generation needs to reinterpret major historical figures in light of its own experience. Cornelis Augustijn's intellectual biography of Erasmus is above all a book for readers in the nineties. Its appeal is not restricted to a narrow circle of scholars but reaches out to all students of cultural history. In this comprehensive introduction to Erasmus' life, works, and thought, Augustijn shows himself well attuned to the scholarship of the last twenty years. Familiar with the grammatical and rhetorical roots of Erasmus' intelligence, with his religious views and immense importance as one of the architects of modern thought, Augustijn presents in this volume a new and important analysis of 'what mattered to Erasmus.'

CORnelis augustijn is Professor of Church History, Free University of Amsterdam.

J.C. GRAYSON lives in Liverpool. He has translated numerous scholarly books from various languages. 


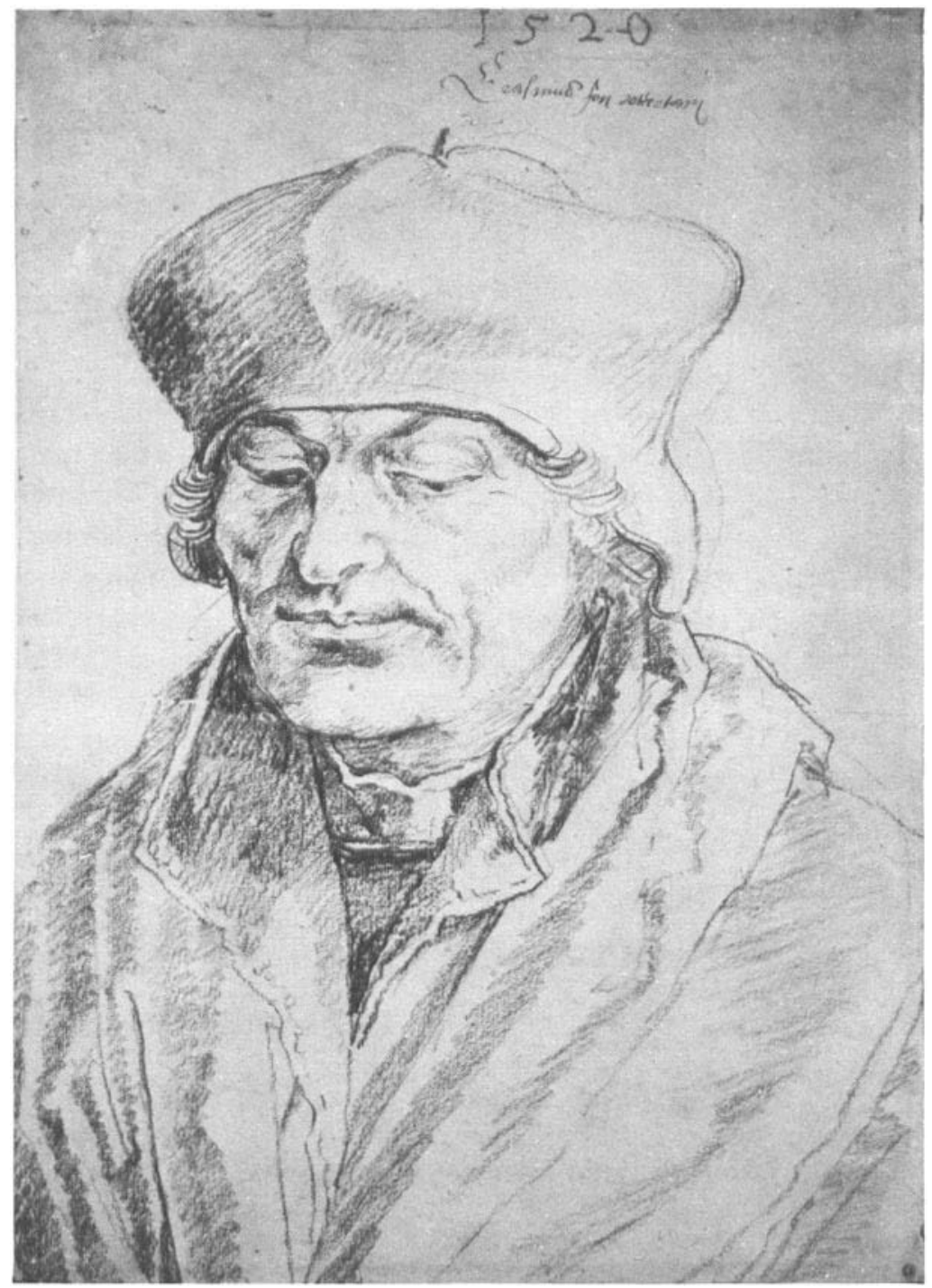

\section{Erasmus}

Charcoal drawing by Albrecht Dürer, 1520 The Louvre, Paris 


\section{Cornelis Augustijn}

\section{ERASMUS \\ His Life, Works, and Influence}

ş.

translated by

J.C. Grayson

UNIVERSITY OF TORONTO PRESS

Toronto Buffalo London 


\section{www.utppublishing.com}

Originally published as

Erasmus von Rotterdam: Leben - Werk - Wirkung

(C) C.H. Beck'sche Verlagsbuchhandlung

(Oscar Beck) München 1986

English translation

(C) University of Toronto Press 1991

Toronto Buffalo London

Printed in Canada

Reprinted in paperback 1995

The English translation from the Dutch original was supported by a grant from the Prins Bernhard Fonds.

$$
\begin{aligned}
& \text { ISBN 0-8020-5864-7 (cloth) } \\
& \text { ISBN 0-8020-7177-5 (paper) }
\end{aligned}
$$

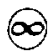

Printed on acid-free paper

\section{Canadian Cataloguing in Publication Data}

$$
\begin{gathered}
\text { Augustijn, C., 1928- } \\
\text { Erasmus }
\end{gathered}
$$

Translation of: Erasmus, vernieuwer van kerk en theologie.

ISBN 0-8020-5864-7 (bound) ISBN 0-8020-7177-5 (pbk.)

1. Erasmus, Desiderius, d. 1536. I. Title.

$$
\begin{array}{lll}
\text { B785.E64A915 } 1991 & 199^{\prime} .492 & \text { C91-095059-8 }
\end{array}
$$

